\title{
Per-operative fluid therapy, vasopressor and transfusion rate in DIEP-flap breast reconstruction. A series of cases
}

\section{Fluidoterapia, uso de vasopresores y tasa transfusional peroperatoria en la re- construcción mamaria con colgajo DIEP. Una serie de casos}

\author{
Ana Tejedor Navarro Ph.D. ${ }^{1 *}$, Carmen Deiros García Ph.D. ${ }^{1}$, Aleix Carmona Blesa Ph.D. ${ }^{1}$, Marina Vendrell Jordà M.D. Ph.D², \\ Josep Masdeu Castellví M.D. Ph.D ${ }^{1}$ \\ Anesthesiology Department, Hospital Sant Joan Despí Moisès Broggi, Barcelona, Spain. \\ 2 Anesthesiology Department, Hospital Clínic of Barcelona, Barcelona, Spain.
}

Fecha de recepción: 01 de febrero de 2021 / Fecha de aprobación: 10 de marzo de 2021

\begin{abstract}
Objective: Anesthetic management in DIEP-flap breast reconstruction surgery may influence the appearance of postoperative complications. Fluid therapy, vasopressor use, and blood management are controversial. The aim was to audit hemodynamic management and to assess its impact on perioperative outcomes. Material and Methods: Sixty-seven cases of DIEP-flap breast reconstruction were reviewed. Data collected: anthropometric data; ASA score; comorbidities; timing of reconstruction (immediate/delayed), type of reconstruction (unilateral/bilateral); length of surgery; per-operative complications; per-operative fluid therapy, use of vasopressors, transfusion rate; re-intervention requirements; surgical success rate; hospital stay, and readmission rate. Results: Median crystalloid infusion rate was $3.18(2.63-3.76) \mathrm{ml} / \mathrm{kg} / \mathrm{h}$ in the first 24 hours. Intraoperatively, colloids were administered in $35(52 \%)$ patients at a median infusion rate of $1.40(1.08-1.86) \mathrm{ml} / \mathrm{Kg} / \mathrm{h} ; 21(60 \%)$ of them presented some postoperative complication. Hypotensive events were registered in $13(19 \%)$ patients; $9(69 \%)$ suffered some postoperative complication. The only vasopressor used was Ephedrine in 14 (21\%) patients, at a median dose of 0 (0-6) mg. Red blood cell (RBC) transfusion was required in $18(27 \%)$ patients. All of the patients who were transfused, $11(61 \%)$ presented some postoperative complication. Hospital stay was 7 (7-9) days. Surgery was successful in 46 (69\%) patients and readmission was necessary in 11 $(16 \%)$ patients. Conclusions: Colloids administration, intraoperative hypotensive events, RBC transfusion, and delayed surgery are variables that could increase the risk of postoperative complications in our series.
\end{abstract}

Key words: Anesthesia, postoperative complications, perforator flap, breast reconstruction.

\section{RESUMEN}

Objetivo: El manejo anestésico en la cirugía de reconstrucción mamaria con colgajo DIEP podría influir en la aparición de complicaciones posoperatorias. La fluidoterapia, el uso de vasopresores y la tasa transfusional son motivo de controversia. Nuestro objetivo fue auditar el manejo hemodinámico y valorar su impacto en los resultados perioperatorios. Material y Métodos: Analizamos 67 pacientes programadas para reconstrucción mamaria con colgajo DIEP. Datos registrados: antropométricos; ASA; comorbilidades; momento de la reconstrucción (inmediata/diferida); tipo de reconstrucción (unilateral/bilateral); duración quirúrgica; complicaciones perioperatorias; fluidoterapia, vasopresores y tasa transfusional peroperatorios; tasa de reintervención, reingresos y éxito de la cirugía; estancia hospitalaria. Resultados: La velocidad promedio de infusión de cristaloides fue de 3,18 $(2,63-3,76) \mathrm{ml} / \mathrm{kg} / \mathrm{h}$ en las primeras $24 \mathrm{~h}$. Intraoperatoriamente se administraron coloides en $35(52 \%)$ pacientes a una velocidad promedio de infusión de $1,40(1,08-1,86) \mathrm{ml} / \mathrm{kg} / \mathrm{h}$, presentando complicaciones posoperatorias en $21(60 \%)$ casos. Trece $(19 \%)$ pacientes presentaron eventos hipotensivos intraoperatorios, registrándose complicaciones en 9 (69\%). El único vasopresor utilizado fue la efedrina en 14 (21\%) pacientes, a una dosis mediana de 0 (0-6) mg. Requirieron transfusión sanguínea 18 (27\%) pacientes. Del total de pacientes transfundidos, $11(61 \%)$ habían presentado alguna complicación posoperatoria. La cirugía fue un éxito en 46 (69\%) casos. La estancia hospitalaria fue de 7 (7-9) días y el reingreso fue necesario en 11 (16\%) casos. Conclusiones: La administración de coloides, los eventos hipotensivos intraoperatorios, la transfusión de hemoderivados y la cirugía con reconstrucción tardía son variables que podrían incrementar el riesgo de complicaciones posoperatorias.

Palabras clave: Anestesia, complicaciones posoperatorias, colgajo perforante, reconstrucción mamaria. 


\section{Introduction}

F ree tissue transfer has become an indispensable technique in plastic surgery. In breast reconstruction surgery, the deep inferior epigastric perforator (DIEP) flap has shown good functional and aesthetic results, allowing preservation of the abdominal wall with less morbidity relating to the area from which the graft is extracted[1].

Several factors related to the perioperative period may have the potential to influence success rate of surgery. Good surgical technique and the skill of the surgeon are key; however, good results cannot be assured without adequate perioperative anesthetic management, by controlling hemodynamics and assuring an appropriate graft blood flow[2]. It is essential to keep patients normovolemic in order to maintain an adequate cardiac output and, consequently, appropriate blood flow at graft level. Vasopressors could potentially be associated with vasospasm at this level, making perfusion difficult[3]. This topic is currently in controversy[4],[5], however, the tradition and individual experiences of surgeons make them dogmatically refuse vasopressors for pressure control during microvascular procedures[6]. This is the reason why the anesthesiologist usually chooses to optimize tissue perfusion by increasing cardiac output with a liberal fluid strategy, using vasopressors only when strictly necessary[4], even if this strategy comprises a risk of fluid overload and complications in the postoperative period[7]-[10].

Another factor to consider is the ideal value of hemoglobin $\mathrm{Hb}$ which, for this type of surgery, is unknown. Hb values lower than $10 \mathrm{~g} / \mathrm{dL}$ have been classically established as transfusion triggers to maintain optimal perfusion of the graft[11], without taking into account complications associated to blood product transfusion[12]. The existing bibliography regarding the reassessment of optimal transfusion levels is minimal[13].

The objective of this study was to audit hemodynamic management through fluid therapy, vasopressor infusion, and blood transfusion in DIEP flap surgery, and describe the outcomes.

\section{Material and Methods}

After IRB approval (number protocol 19/77), an observational descriptive study was performed. We recorded data from all patients who underwent DIEP flap surgery at the Hospital Sant Joan Despí Moisès Broggi and Hospital General de I’Hospitalet (Consorci Sanitari Integral), between January 2014 and December 2019.

Inclusion criteria were patients who underwent breast reconstruction surgery through DIEP flap technique and age $>18$ years old.

Data was obtained via retrospective review of clinical stories, including the anesthesia sheet, nurse charts and plastic surgeon registries. Predictor variables were selected based on previous studies[9] and factors to a priori affect the outcomes.

Variables included were:

- Preoperative variables: anthropometric data, American Society of Anesthesiologists Classification of Physical Status System (ASA score), comorbidities, previous chemotherapy (QT), previous radiotherapy (RT), preoperative hemoglobin (Hb).

- Intraoperative variables: length of surgery, surgical com- plications, crystalloid and colloid infusion rate, vasopressor administered, red blood cell (RBC) transfusion rate, hypotensive events and surgical predictors as timing of reconstruction (immediately/delayed) and type of reconstruction (unilateral/bilateral).

- Postoperative variables: colloid and crystalloid infusion rate in the first 24 hours, vasopressor administered, complications and need to re-operate, postoperative $\mathrm{Hb}$ at 24 hours, RBC transfusion, surgery success rate, hospital stay and need for readmission.

\section{Management of patients undergoing DIEP surgery flap}

Under standard monitoring (electrocardiogram, pulse oximetry, and noninvasive blood pressure), a peripheral venous access was obtained, and intravenous midazolam (1-2 mg) was administered for anxiolysis.

The procedure was performed under combined or general anesthesia. After anesthetic induction with fentanyl $(1.5 \mathrm{mcg} /$ $\mathrm{kg})$, propofol $(1.5-2 \mathrm{mg} / \mathrm{kg})$ and rocuronium $(0.6 \mathrm{mg} / \mathrm{kg})$, patients were transorally intubated. Depending on each anesthesiologist's practice, different perioperative analgesic strategies were used (paravertebral block, transversus abdominis plane block, interpectoral block, epidural technique, or BIC morphine for per-operative pain control). Anesthesia was maintained using sevoflurane (Baxter Dräger, Vapor 2000). Intravenous fentanyl was administered for pain control, if needed.

Blood pulse pressure was continually monitored via an arterial line for a mean arterial blood pressure (MAP) target above $70 \mathrm{mmHg}$; as well as urinary output. Intraoperative fluid infusion rate with crystalloids was decided by the anesthesia team based on the patient's urinary output and MAP, following net zero fluid therapy strategy. In general, crystalloids were used exclusively for intravenous hydration. Colloids were used intraoperatively in case of excessive bleeding, or when deemed that volume replacement could improve flap perfusion. The decision whether or not to use vasopressors was made by the anesthesia team on a case-by-case basis. RBC transfusion was administered according to our hospital's current protocol, which follows the ESA guidelines for management of severe perioperative bleeding[14].

After surgery, patients were extubated and transferred to the post-anesthesia care unit (PACU), where they remained for the first 24 hours for pain, bleeding, and flap perfusion control. Patients were kept warm to avoid vascular complications due to vasoconstriction. Surgical flap was checked hourly, evaluating color, temperature, aspect, turgor, and capillary refill. Lowmolecular-weight heparin (LMWH) was started prophylactically at $1 \mathrm{mg} / \mathrm{kg}, 6$ hours after surgery, and maintained during at least 10 days to avoid thrombotic occlusion of small vessels. In case of complication, LMWH was maintained longer.

At PACU, maintenance fluid infusion rate with crystalloids was determined by the anesthesia team based on the patient's blood pressure, heart rate, and urine output (>0.5 ml/kg/h). Colloids were used in case of excessive bleeding, or when it was considered that volume replacement could improve flap perfusion. As in intraoperative management, the decision whether or not to administer vasopressors was made by the anesthesia team on a case-by-case basis.

If there were no complications in the first $24 \mathrm{~h}$ after surgery, 
the patient was discharged to the conventional hospital ward. If within the first $24 \mathrm{~h}$ any kind of complication ensued, in most cases surgical revision was required following the criteria of the plastic surgeon. After hospital discharge, patients received a postoperative evaluation by the plastic surgeon specialist at 2 and 4 weeks after surgery.

We recorded postoperative complications, including both medical and surgical complications. Medical complications included any event involving a distant organ or site other than the operative field. Surgical complications included events that occurred at the graft or recipient site, such as a total or partial flap loss, venous flap congestion, infection, hematoma, seroma, fat necrosis (defined as a palpable firmness identified by physical examination during postoperative evaluation or detected by ultrasound), and wound problems. The latter included wound dehiscence and superficial skin necrosis related to breast reconstruction.

Hypotensive events were defined as a decrease in systolic blood pressure below 20\% from baseline. Length of surgery was recorded as the elapsed time in hours between the documented time of incision and the documented time of closure. Reoperation was defined as a return to the operating room during the hospital admission corresponding to DIEP flap surgery. Readmission was defined as returning to hospital within 30 days after discharge. Surgery was considered successful if there was graft integrity upon hospital discharge. Parameters related to a longer (> 4 weeks) follow up period were not considered for this study.

\section{Statistical analysis}

Results are reported as median (25-75 th percentile) or number of patients (\%). Statistical analyses were carried out using SPSS v 22.0

\section{Results}

Sixty-seven patients were included. The median age was 51 (48-63) years and body mass index (BMI) was 27.55 (24.03$30.47) \mathrm{kg} / \mathrm{m}^{2}$. Of all patients, 2 (3\%) patients were ASA I, 61 (91\%) ASA II, and 4 (6\%) ASA III. Regarding comorbidities, 19 (29\%) patients presented arterial hypertension (HTA) and 5 (7\%) patients, diabetes mellitus (DM). Previous QT and RT were performed in $42(63 \%)$ and $11(16 \%)$ patients, respectively.

Length of surgery was 300 (270-360) minutes (min). Surgical time was longer in delayed reconstruction 360 (290-425) min vs immediate reconstruction 300 (240-352) min; and according to the type of reconstruction, unilateral reconstruction lasted 300 (270-360) min vs 300 (240-370) min in bilateral reconstruction.

Nine $(14 \%)$ patients suffered some kind of intraoperative complication: 8 presented bleeding requiring 2 (0-3.25) RBC units, and 1 had a vascular anastomosis failure. As for postoperative complications, 31 (46\%) patients presented postoperative complications, with $27(40 \%)$ requiring re-intervention. Complications were: 9 partial and 11 total necrosis flap (all of which required re-intervention), 2 hematomas (one treated conservatively and the other requiring surgical revision), 2 cases of surgical wound infection (one requiring antibiotic therapy and the other surgical revision), 1 lymphedema (conservative treatment), 3 cases of congestive flap and 1 thrombosis flap (all requiring surgical revision), and 1 case of bleeding at graft level of the right anterior rectus that required embolization of a perforating artery from the inferior epigastric artery. There was one medical complication, a paroxysmal supraventricular tachycardia that required medical treatment.

Immediate reconstruction was performed in 50 (75\%) patients and delayed in 17 (25\%) patients. In immediate reconstruction 21 (42\%) patients presented with postoperative complications, and in delayed reconstruction 10 (59\%) patients. Unilateral surgery was performed in 34 (51\%) patients; 13 (38\%) of them presenting complications. Bilateral surgery was performed in 33 (49\%) cases; in 18 (55\%) patients postoperative complication was observed.

As for patients who received previous RT and QT, 6 (55\%) and $20(48 \%)$ of cases suffered postoperative complications, respectively.

\section{Evaluation of fluid therapy administered}

Median crystalloid infusion rate was $6.03(4.34-8.08) \mathrm{ml}$ $\mathrm{kg} / \mathrm{h}$ intraoperatively and $3.18(2.63-3.76) \mathrm{ml} / \mathrm{kg} / \mathrm{h}$ in the first 24 hours. Intraoperative colloids were administered in 35 (52\%) patients at a median infusion rate of $1.40(1.08-1.86) \mathrm{ml} / \mathrm{kg} / \mathrm{h}$; $21(60 \%)$ of them presented with some postoperative complication. No colloids were administered at PACU. When intraoperative hypotensive events were analyzed, 13 (19\%) cases were registered. Nine $(69 \%)$ of them presented with postoperative complications.

\section{Evaluation of vasopressors administered}

In 14 patients (21\%) vasopressors were used intraoperatively. In all cases, the only vasopressor used was Ephedrine, at a median dose of 0 (0-6) mg. No vasopressors were needed at PACU.

\section{Evaluation of RBC transfusion. Preoperative and postop- erative $\mathrm{Hb}$}

Median preoperative $\mathrm{Hb}$ was 12.81 (11.50-13.41) g/dL; whereas postoperative $\mathrm{Hb}$ in the first $24 \mathrm{~h}$ was 10.40 (9.32$11.50) \mathrm{g} / \mathrm{dL}$. RBC transfusion was required in 18 (27\%) patients, in $7(1 \%)$ of them intraoperatively. Median RBC transfusion was $2(0-3.25)$ units intraoperatively, and 0 (0-1) units postoperatively. Per-operative RBC transfusion rate was 0 (0-1) units. From all patients transfused, $11(61 \%)$ registered some kind of complication. The postoperative complications that required RBC transfusion were partial and total necrosis flap and the two hematomas. The hematological parameters related to the type and timing of reconstruction are detailed in Table 1.

Hospital stay was 7 (7-9) days. Surgery was deemed successful in $46(69 \%)$ patients. Readmission rate was 16\% (11 patients). These were due to: removal of the breast prosthesis placed in one of the cases of total necrosis (1 case), general discomfort (2 cases), dehiscence of surgical wound at abdominal level requiring conservative treatment (1 case), wound infection (2 cases), necrosis that required reoperation and vacuum-assisted closure therapy (4 cases), and one seroma that was solved by placing drainages. 


\begin{tabular}{lccc}
\hline & Tabla 1 \\
\hline & Pre Hb (g/dL) & RBC (units) & Post Hb (g/dL) \\
Unilateral reconstruction & $12.95(11.85-14.05)$ & $0(0-0)$ & $10.45(9.80-11.70)$ \\
Bilateral reconstruction & $12.60(11.35-13.15)$ & $0(0-1)$ & $9.7(8.60-11.45)$ \\
Immediate reconstruction & $12.35(11.40-13-40)$ & $0(0-1)$ & $10.35(9.30-11.50)$ \\
Delayed reconstruction & $13(12.65-13.65)$ & $0(0-1)$ & $10.50(9-11.8)$ \\
\hline
\end{tabular}

$\mathrm{Hb}$ : hemoglobin; RBC: red blood cell.

\section{Discussion}

Knowledge of the factors that could influence outcomes in free flap surgery for breast reconstruction is essential to any anesthesiologist and surgeon performing this kind of surgery. Our incidence of complications was $46 \%$, in accordance with results described in other series[15]. Our patients underwent restrictive fluid therapy, as recommended by literature[9],[10],[16]. Several studies propose an administration of crystalloids between $3.5-6 \mathrm{ml} / \mathrm{kg} /$ hour during the first $24 \mathrm{~h}[7],[8]$. In our study, crystalloid infusion rate was $3.18(2.63-3.76) \mathrm{ml} / \mathrm{kg} / \mathrm{h}$ in the first 24 hours. Liberal fluid therapies are associated with a higher rate of complications, be them local, such as increased flap failure or revision, or systemic[8]-[10]. We also know that crystalloid infusion rate is an independent predictor for the appearance of complications in breast reconstruction surgery[8],[10]. All of this may be due to interstitial edema that can compromise flap perfusion[17]. As for crystalloids, in our series, $60 \%$ of patients who received colloids had some postoperative complications. A possible explanation could be the coagulopathy induced by them. Their interference in the coagulation cascade has been described as leading to a reduction in VWF, platelet dysfunction, reduction in FVIII levels, and potential dysfibrinogenemia[18]. In an animal study performed by Shick et al.[19], severe coagulopathy due to decreased platelet aggregation, impaired microcirculation, and an increase in cytokines IL-1 $\beta$, IL-6, IL 10 and TNF $\alpha$ levels was observed[19],[20]. We should keep in mind that colloids are indicated in a hypovolemic context, so their use is often associated with an initial appearance of intraoperative hypotensive events. Of all our patients who presented an intraoperative hypotensive event, $69 \%$ suffered complications. Therefore, our hypothesis is that both intraoperative hypotensive events and colloids administration could increase the appearance of postoperative complications. However, by the nature of our study, we cannot establish causality.

The use of vasopressors was very low in this study. The contraindication of intraoperative vasopressors has long been a fervently maintained belief within the field of microvascular surgery, as these drugs hypothetically reduce flap perfusion, leading to an increased likelihood of complications due to vasoconstriction. This has not been demonstrated in either the systematic review carried out by Mostakef et al[7] or the study by Chen et al[21]. In a study by Eltorai et al[4], which analyzed 475 breast reconstructions using the DIEP technique, ephedrine administration was even associated with a decrease in the risk of intraoperative complications, including vasospasm, thrombosis, and venous congestion, by improving flap perfusion. Optimal intraoperative fluid therapy is associated with lesser use of in- traoperative vasopressors, as probably happened in our series.

RBC transfusion was required in $27 \%$ patients, with $61 \%$ of them suffering some postoperative complication. A recent review concluded that intraoperative blood transfusion could be associated with higher rates of postoperative complications, reinterventions, and surgical wound infections[22],[23]. Bernard et al.[24] found a strong association between intraoperative RBC transfusion and post-surgical mortality and morbidity, the hypothesis being that allogeneic blood transfusion modulates the immune system in innumerable ways, many of them deleterious[25]. However, the exact mechanisms responsible for these observed effects have not been elucidated yet. Furthermore, hemodilution can reduce blood viscosity. These may be beneficial in preventing thrombus formation and promote flap shock recovery[26]. Contemporary research suggests a reduction in transfusion-related complications and expenses, with no increase in surgical complications, utilizing lower transfusion thresholds[27]. Therefore, both ESA guidelines and several studies recommend a restrictive transfusion strategy, treating clinically symptomatic patients or those with a hemoglobin level less than $7 \mathrm{~g} / \mathrm{dL}[7],[14]$.

In our series, transfusion rates are similar to those reported by Kim et al.[22]. Other studies report transfusion rate as high as $80.3 \%$. One explanation could be that the decision for blood transfusion was not made with any strict clinical criteria ${ }^{28,}$ whereas our blood transfusion protocols have the same restrictive thresholds as the study described by Kim et al.[22].

Several studies conclude that hemoglobin should be optimized before surgery $(\mathrm{Hb}>10 \mathrm{~g} / \mathrm{dL})[8]$,[9],[29], as preoperative $\mathrm{Hb}$ values below $11 \mathrm{~g} / \mathrm{dL}$ are associated with longer hospital stay and worse flap outcomes[9], and values below $10 \mathrm{~g} / \mathrm{dL}$ are a significant predictor of graft thrombosis and failure[29]. Our preoperative $\mathrm{Hb}$ values were higher than $10 \mathrm{~g} / \mathrm{dL}$.

Finally, regarding surgical characteristics, in delayed reconstruction, $59 \%$ of patients suffered postoperative complications. Mastectomy skin flaps are often scarred and less compliant, and a higher rate of free flap thrombosis has been described[30].

Our study has some limitations. Being an observational descriptive study, intraoperative analgesia management of patients did not follow strict protocols and this produces an important bias. Furthermore, data was collected retrospectively, with some data missing, compromising data analysis and reducing power of statistical conclusions. However, having a protocol for RBC transfusion helps diminish this bias. It will be of paramount importance for future prospective studies to further evaluate the impact of hemodynamic parameters on outcomes in DIEP surgery. 


\section{Conclusions}

Colloids administration, intraoperative hypotensive events, RBC transfusion, and delayed surgery are variables that could increase the risk of postoperative complications in our series.

Acknowledgements: The authors thank Sara Espejo Malagón for her collaboration and support in carrying out the study.

\section{References}

1. Yueh J, Slavin S, Adesiyun T, y cols. Patient satisfaction in postmastectomy breast reconstruction: A comparative evaluation of DIEP, TRAM, latissimus flap and implant techniques. Plast Reconstr Surg 2010; 125:1585-1595.

2. Adams J, Charlton P. Anesthesia for microvascular free tissue transfer. Br J Anaesth (CEPD Reviews) 2003;3:33-37.

3. Massey MF, Gupta DK. The effects of systemic phenylephrine and epinephrine on pedicle artery and microvascular perfusion in a pig model of myoadipocutaneous rotational flaps. Plast Reconstr Surg 2007;120:1289-99.

4. Szabo Eltorai A, Huang CC, Lu JT, Ogura A, Caterson SA, Orgill DP. Selective intraoperative vasopressor use is not associated with increased risk of DIEP flap complications. Plast Reconstr Surg 2017; 140:70e-7e.

5. Ibrahim AM, Kim PS, Rabie AN, Lee BT, Lin SJ. Vasopressors and reconstructive flap perfusion: a review of the literature comparing the effects of various pharmacologic agents. Ann Plast Surg 2014:73:245-8.

6. Hong JPJ, Suh HSP. Discussion: selective intraoperative vasopressor use is not associated with increased risk of DIEP flap complications. Plast Reconstr Surg 2017;140:78e-9e.

7. Motakef S, Mountziaris PM, Ismail IK, Agag RL, Patel A. Emerging paradigms in perioperative management for microsurgical free tissue transfer: review of the literature and evidence based guidelines. Plast Reconstr Surg 2015;135:290-9.

8. Zhong T, Neinstein R, Massey C, y cols. Intravenous fluid infusion rate in microsurgical breast reconstruction: important lessons learned from 354 free flaps. Plast Reconstr Surg 2011;128:115360.

9. Clark JR, McCluskey SA, Hall F, y cols. Predictors of morbidity following free-flap reconstruction for cancer of the head and neck. Head Neck 2007:29:1090-101.

10. Ettinger KS, Arce K, Lohse CM, y cols. Higher perioperative fluid administration is associated with increased rates of complications following head and neck microvascular reconstruction with fibular free flaps. Microsurgery 2017;37:128-36.

11. Perioperative red cell transfusion. NIH Consens Dev Conf Consens Statement 1988; 7:1-19

12. Hill GE, Frawley WH, Griffith KE, Forestner JE, Minei JP. Allogeneic blood transfusion increases the risk of postoperative bacterial infection: a meta-analysis. J Trauma 2003;54:908-14.

13. Velanovich V, Smith DJ Jr, Robson MC, Heggers JP. The effect of hemoglobin and hematocrit levels on free flap survival. Am Surg 1988;54(11):659-663.

14. Kozek-Langenecker SA, Ahmed AB, Afshari A, y col. Management of severe perioperative bleeding: guidelines from the
European Society of Anaesthesiology: First update 2016. Eur J Anaesthesiol 2017; 34:332-395.

15. Hofer S, Damen T, Mureau M, Rakhorst H, Roche N. A Critical Review of Perioperative Complications in 175 Free Deep Inferior Epigastric Perforator Flap Breast Reconstructions. Ann Plast Surg 2007: 59:137-142.

16. Brandstrup B, Tonnesen $H$, Beier-Holgersen $R$, y col. Effects of intravenous fluid restriction on postoperative complications: comparison of two perioperative fluid regimens: a randomized assessor-blinded multicenter trial. Ann Surg 2003;238:641-8.

17. Hidalgo DA, Jones CS. The role of emergent exploration in free tissue transfer. A review of 150 consecutive cases. Plast Reconstr Surg 1990;86:492-499.

18. Fenger-Eriksen C, Anker-Møller E, Heslop J, Ingerslev J, Sørensen B. Thrombelastographic whole Blood Clot Formation After Ex Vivo Addition of Plasma Substitutes: Improvements of the Induced Coagulopathy With Fibrinogen Concentrate. Br J Anaesth 2005;94(3):324-9.

19. Schick MA, Isbary JT, Stueber T, y col. Effects of crystalloids and colloids on liver and intestine microcirculation and function in cecal ligation and puncture induced septic rodents. BMC Gastroerol 201nte2; 12: 179.

20. Hartog CS, Reuter D, Loesche W, Hofmann M, Reinhart K. Influence of hydroxyethyl starch (HES) 130/0.4 on hemostasis as measured by viscoelastic device analysis: A systematic review. Intensive Care Med 2011;37:1725-1737.

21. Chen C, Nguyen MD, Bar-Meir E, y col. Effects of vasopressor administration on the outcomes of microsurgical breast reconstruction. Ann Plast Surg 2010;65:28-31.

22. Kim BD, Ver Halen JP, Mlodinow AS, Kim YIS. Intraoperative transfusion of packed red blood cells in microvascular free tissue transfer patients: Assessment of 30-day morbidity using the NSQIP dataset. J Reconstr Microsurg 2014;30:103-114.

23. Liu SA, Wong YK, Poon CK, Wang CC, Wang CP, Tung KC. Risk factors for wound infection after surgery in primary oral cavity cancer patients. Laryngoscope 2007;117:166-171.

24. Bernard AC, Davenport DL, Chang PK, Vaughan TB, Zwischenberger JB. Intraoperative transfusion of $1 \mathrm{U}$ to $2 \mathrm{U}$ packed red blood cells is associated with increased 30-day mortality, surgicalsite infection, pneumonia, and sepsis in general surgery patients. J Am Coll Surg 2009;208(5):931-937, e1-e2, discussion 938-939.

25. Raghavan M, Marik PE. Anemia, allogenic blood transfusion, and immunomodulation in the critically ill. Chest 2005;127(1): 295307.

26. Qiao Q, Zhou G, Chen GY, Zhang F, Buncke HJ. Application of hemodilution in microsurgical free flap transplantation. Microsurgery 1996;17(9):487-490.

27. Rossmiller SR, Cannady SB, Ghanem TA, Wax MK. Transfusion criteria in free flap surgery. Otolaryngol Head Neck Surg 2010; 142(3):359-364.

28. Ting J, Rozen WM, Le Roux CM, Ashton MW, Tutor EG. Predictors of blood transfusion in deep inferior epigastric artery perforator flap breast reconstruction. J Reconstr Microsurg 2011; 27(4):233-238

29. Hill JB, Patel A, Del Corral GA, y col. Preoperative anemia predicts thrombosis and free flap failure in microvascular reconstruction. Ann Plast Surg 2012;69:364-367.

30. Masoomi H, Clark EG, Paydar KZ, y col. Predictive risk factors of free flap thrombosis in breast reconstruction surgery. Microsurgery 2014;34:589-94. 